\title{
EFFECT OF WATER STRESS ON THE MORPHOLOGICAL GROWTH OF VERNONIA AMYGDALINA SEEDLINGS
}

\author{
Osinaike, Titilola Savier \\ Department of Botany \\ Lagos State University, Ojo, Lagos, Nigeria
}

\author{
Ezenwata, Ifeoma Sussan \\ Department of Biological Sciences \\ Chukwuemeka Odumegwu Ojukwu \\ University, Uli, Anambra, Nigeria \\ Anyaegbu, Chiamaka Frances \\ Department of Biological Sciences \\ Chukwuemeka Odumegwu Ojukwu \\ University, Uli, Anambra, Nigeria
}

\begin{abstract}
Vernonia amygdalina (Bitter-leaf) is a plant whose consumption (leaf and stem) by human races especially Nigeria cannot be underestimated. It is mostly consumed because of its nutritional and medicinal uses in correcting some ailments such as high blood sugar, hypertension, and so on. Vernonia amygdalina growth is hinged on the availability or absence of water in relation to soil. Thus, this study assessed the effect of water stress on the morphological growth of Vernonia amygdalina seedlings. The stem cuttings were obtained from viable growing bitter-leaf plant situated on a small well cultivated garden with only bitter-leaf plants. The experiment was carried out at the Greenhouse of the Botanical Garden of Lagos State University, Ojo. The data were analyzed and result presented in table and bar graph. The result showed that although $V$. amygdalina can be planted using all types of water treatment as observed in this experiment, the result of the three watering regime shows that the best and favourable growth environment for this plant is normal wet treatment water regime (wetting everyday) followed by water logged treatment water regime (excess water) and the least favourable growth environment which can be manageable in absence of the two first mentioned water treatment is the drought treatment (wetting once a week). The amount of water available to plant will affect the rate of photosynthesis. If the plant does not have enough water, the plant's stomata will shut and the plant will be deprived of carbon dioxide.
\end{abstract}

Keywords - Bitter-leaf, water stress, drought and waterlogged.

\author{
Onyemeka, Regland Michael \\ Department of Botany \\ Lagos State University, Ojo, Lagos, Nigeria \\ Ogun, Mautin Lawrence \\ Department of Botany \\ Lagos State University, Ojo, Lagos, Nigeria
}

Akharia, Bright E.

Department of Botany

Lagos State University, Ojo, Lagos, Nigeria

\section{INTRODUCTION}

The survival of plants and animals relies upon water. It is basically required by plants for photosynthesis, nutrient uptake and transportation, keeping up turgidity and in addition lowering canopy temperature (Farooq et al. 2009).Water regime is a primary driver of water flow over a given time and predictability of inundation and drying phases (Rea and Ganf, 1994). A water stress may conceivably arise either due to a deficient or an excess of water (Sena and Kozlowski, 1980). Water potential in higher plants is chiefly controlled by the status of soil moisture. Water stress causes both quantitative and qualitative decrease in plant growth, a decrease in shoot growth expectedly the growth of leaves, which is more sensitive than root growth (Sena and Kozlowski, 1980; Jockson and Drew, 1984). Zingaretti et al. (2011) reported that during vegetative stage of growth, water is essentially required by plant to obtain maximum yield, and that inadequate water uptake in this stage may reduce crop productivity. Under stressful condition, plant growth is usually affected due to changes in physiological and biochemical activity caused by reduced photosynthesis which may affect the yield and productivity of agriculture crop in many regions around the world (Jackson, 1985; Justin and Armstrong, 1987; Jackson, 1990b; Rahman et al., 2004; Johnston, 2005, Rashidi and Seyfi, 2006 and Riccardi et al., 2016).

Vernonia amygdalina Del. is a species of Vernonia which belongs to the family Asteraceae (compositae). Better leaf as it is popularly called grows under a range of ecological zones in Africa and produces large mass of forage (Hutchinson and Dalziel, 1963 in Bonsi et al., 1995a). They are of the most 


\section{International Journal of Engineering Applied Sciences and Technology, 2019 \\ Vol. 4, Issue 7, ISSN No. 2455-2143, Pages 222-228 \\ Published Online November 2019 in IJEAST (http://www.ijeast.com)}

widely consumed leafy vegetable in West and Central Africa owing to its sweet and bitter taste. They are sold fresh or dried, and it is a typical ingredient in soup and stew. V. amygdalina has an astringent taste, which affects its intake (Bonsi et al., 1995a). It is popularly called better leaf due to its multinutritional factors such as alkaloids, saponins, tannins and glycosides (Buttler and Bailey, 1973; Ologunde et al., 1992 in Bonsi 1995b). The plant is mainly cultivated by stem cutting and or seedlings. The plant will not grow unless they are supplied with enough water to maintain their leaves, they must be well hydrated in the face of continuing evaporation (Boyer and Westgate, 2004). The amount of water available to the plant will affect the rate of photosynthesis (Steven et al., 1984). Inadequate water supply causes stomata closure depriving the plant of carbon dioxide (Hardwick, 1984).

The objective of the present study is to investigate the morphological and structural changes induced by water deficit or excess water on bitter leaf to determine the capability of the crop to tolerate water stress.

\section{MATERIALS AND METHODS}

The experiment was carried out in the Greenhouse of the Botanical Garden of the Department of Botany, Lagos State University, Ojo, Lagos, Nigeria.

\section{A. Soil Preparation}

Nursery: Each planting bag of diameter $30 \mathrm{~cm}$ and depth of 40 $\mathrm{cm}$ were filled with $0.5 \mathrm{~kg}$ humus soil and poultry manure. Plant Transplanting: Each planting bags of diameter $30 \mathrm{~cm}$ and depth of $40 \mathrm{~cm}$ were filled with $15 \mathrm{~kg}$ humus soil and poultry manure for actual plant experiment.

\section{B. Nursery}

The stem cuttings of $V$. amygdalina were collected from viable growing bitter-leaf plant situated on a small well cultivated garden with only bitter- leaf plants. The stem cuttings were planted immediately in 100 bags containing humus soil of 0.5 $\mathrm{kg}$. With one plant to one bag, arranged in a row of ten, watered sufficiently and monitored between constantly.

\section{Established Plant}

A set of 90 perforated uniform bags of diameter $30 \mathrm{~cm}$ and depth of $40 \mathrm{~cm}$ filled with $15 \mathrm{~kg}$ of humus soil were used for transplanting. The seedlings from the nursery were transplanted into the new planting bag.

\section{Application of Treatment}

Three watering regimes namely Normal Wet Treatment (Control), Drought Treatment and Water Logged Treatment were used as the treatment for the study. Each water treatment contained 30 plants which were completely randomized. The quantity of water used in each wetting was $75 \mathrm{cl}$. In Normal Wet Treatment, wetting of the plants in this water treatment was done once every day. Normal Wet Treatment is the control for the experiment. Plants in Drought Treatment were wet only on Monday of every week, that is, once in a week) while the plants in Water Logged Treatment were constantly water logged by watering the plant with excess water more than the plant require. A physical observation of puddles of water always on the rhizospehere of the set of plant for water logged treatment was an indicator of constant waterlogging of these set of plants. The three water regime treated plants were carefully monitored during the time of the experiment which lasted for six months.

\section{E. Data Analysis}

Ten seedlings were used from the 100 established plants for the initial measurement of the following morphological data, before the application of treatment; average height of stem cutting established and used for experiment, the average base and oldest leaf length of the established stem cuttings; Leaf breadth; Plant girth; Fresh Weight of Leaf and Petiole. After the application of treatment (water regime), four plants were taken every month end from each water treatment (Normal Wet Treatment (NWT) (control), Drought Treatment (DT) and Water Logged Treatment (WLT)) for destructive measurement of the parameters such as Stem Height (SH), Leaf Length (LL), Leaf Breadth (LB), Plant Girth (PG), Petiole Length (PL), Length of Root (LR), Fresh Weight of Root (FWR) and Fresh Weight of Leaf (FWL) for a period of six months. The average mean of each of the parameters are presented in the table below. At completion of the experiment, 24 Bitter Leaf plants were used from each water regime for destructive experimental measurements.

\section{RESULTS AND DISCUSSION}

The result for the initial morphological data are presented in Table 1 bellow; average height of stem cutting established and used for experiment was $6.00 \mathrm{~cm}$, the average base and oldest leaf length of these established stem cuttings (LL) was 3.00 $\mathrm{cm}$; Leaf breadth (LB) was $1.80 \mathrm{~cm}$; Plant girth $(\mathrm{G})$ was 1.20 $\mathrm{cm}$; Fresh Weight of Leaf (FWL) was $2.10 \mathrm{~g}$ and Petiole was $0.80 \mathrm{~cm}$. The result for each of the measured morphological character was constant for the entire three water regime.

The result of the morphological data after the application of treatment is also presented in Table 1 below. One hundred (100) percent continuous growth without any death was recorded for each water regime, although growth rate was not the same for the three regimes.

Upon analysis of the obtained data, it was determined that the growth of the eight (8) morphological characters varied due to water stress. From the result of the study, differences were recorded on Stem Height (SH), Leaf Length (LL), Plant Leaf Breadth (LB), Plant Girth (PG), Petiole (PL), Length of Root (LR), Fresh Weight of Root (FWR) and Fresh Weight of Leaf (FWL) (Table 1 and Figure 1-8). Restriction of available water content led to decrease of the growth of the eight (8) morphological characters. The performance of the plants 


\section{International Journal of Engineering Applied Sciences and Technology, 2019 \\ Vol. 4, Issue 7, ISSN No. 2455-2143, Pages 222-228 \\ Published Online November 2019 in IJEAST (http://www.ijeast.com)}

under the drought treatment and water logged treatment were below those in the control experiment (normal wet treatment regime).

Adaptation to arid conditions involves increasing root growth despite water deficit (Bauerle et al. 2008). In fact, the degree of tolerance of arid conditions shown by $V$. amygdalina is maybe related to their capability to create new roots under stress conditions (Bonsi et al. 1955). This capability not only increases the hydraulic absorption of roots, but also guarantees transfer of sufficient water and nutrition to shoots (Lovisolo et al. 2010). As the effects of water stress on leaf growth were reviewed (Fig. 2 and 7); it was seen that water stress were significant factors for differences arising in terms of average leaf length and petiole length.

This finding agrees report of Paul (1963) that plant water stress depends on the relative rates of water absorption and water loss rather than on soil water supply alone. Water stress like affects the crop growth and development through a progression of complex physio-biochemical and metabolic procedures at genetic and molecular level, for example, photosynthesis, respiration, uptake of water and nutrient elements, enzymatic activities, metabolism of organic materials, and suppressed or over expression of genes encoding stress proteins and transcription factors (Saba et al. 2001; Villalobos et al. 2004; Farooq et al. 2009).

The findings, obtained with respect to the effects of water stress application on shoot and root growth in the $V$. amygdalina tested in this study, are in agreement with literature data (Eriş et al. 1998; Bertamini et al. 2006; Kliewer et al. 1983; Poni et al. 1993; Winkel and Rambal, 1993; Paranychianakis et al. 2004). According to conducted researches, physiological and biochemical reactions are seen on the plant during an aridity period. The decrease of water in the root area causes abscisic acid (ABA) biosynthesis to increase in roots. Under conditions of inadequate soil moisture, the increase of ABA biosynthesis and accumulation not only leads to the continuation of root growth, but also ensures by both regulating stoma movements and preventing shoot and leaf growth that the loss of water by transpiration decreases (Cramer, 2010; Satisha et al. 2006; Lovisolo et al. 2010). Thus, root:shoot ratio increases in plants and, therefore, it becomes possible to provide sufficient water and nutrition to the plant (Dry et al. 2000).

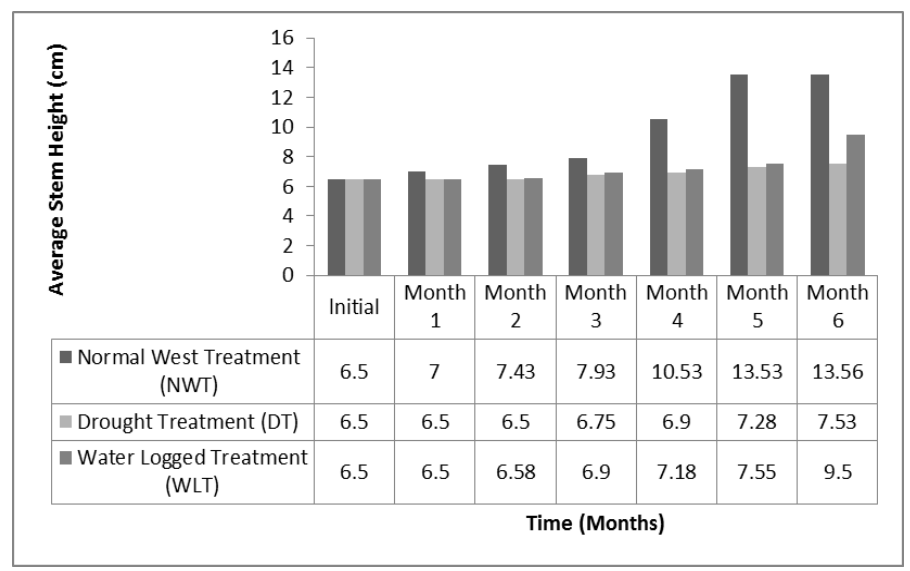

Fig. 1: Effect of Water Regime on the Growth of the Stem Height of Vernonia amygdalina.

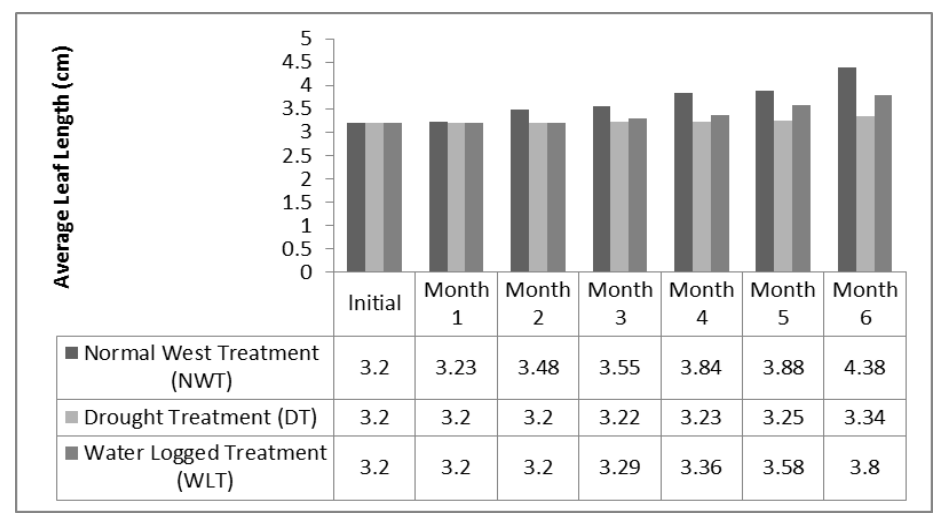

Fig. 2: Effect of Water Regime on the Leaf Length of Vernonia amygdalina.

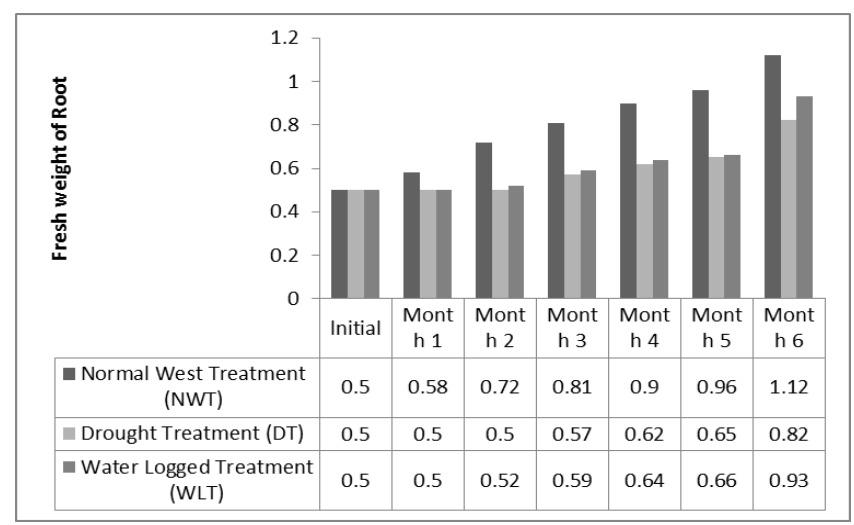

Fig. 3: Effect of Water Regime on the Fresh Weight of Root of Vernonia amygdalina 


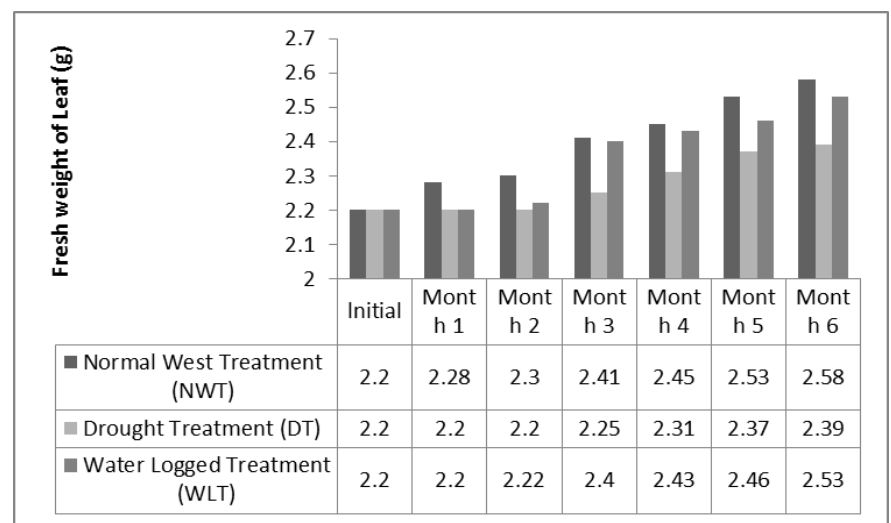

Fig. 4: Effect of Water Regime on the Fresh Weight of Leaf of Vernonia amygdalina.

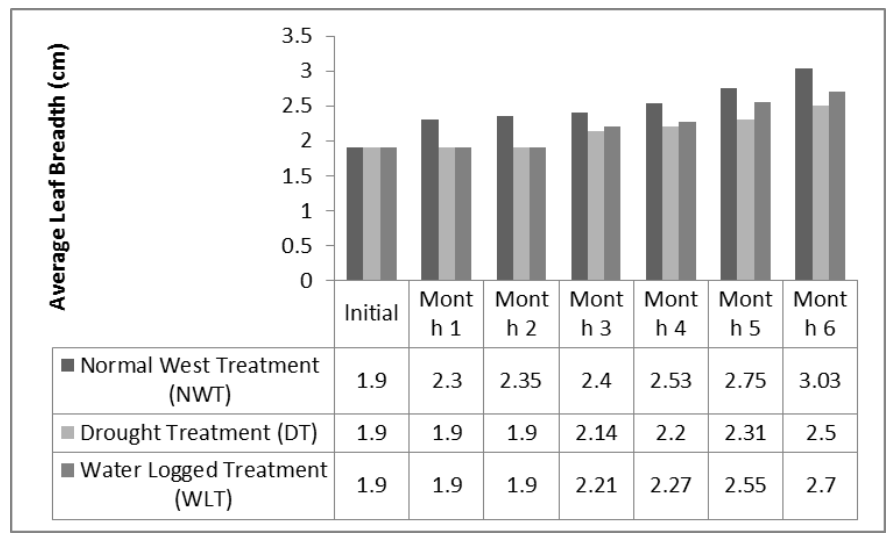

Fig. 5: Effect of Water Regime on the Growth of the Leaf Breadth of Vernonia amygdalina.

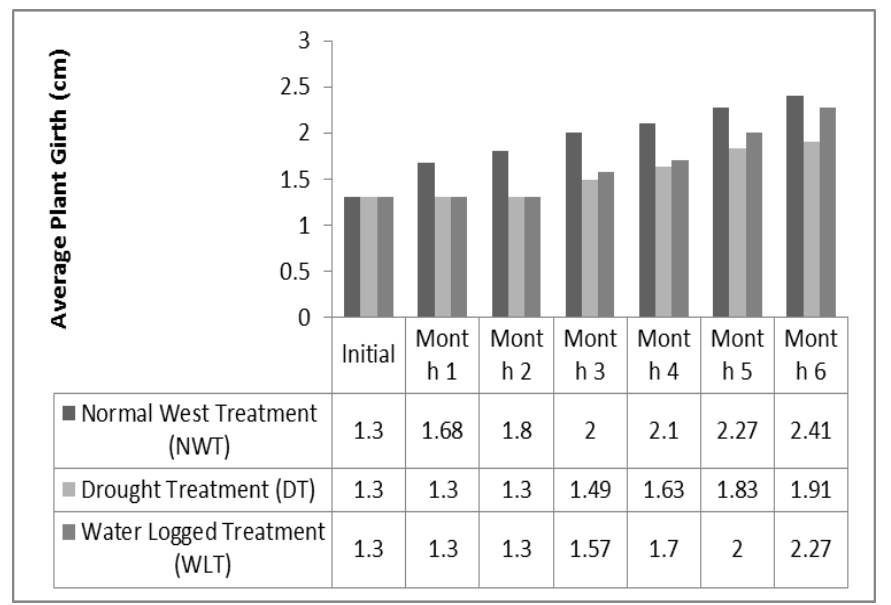

Fig. 6: Effect of Water Regime on the Growth of the Plant Girth of Vernonia amygdalina.

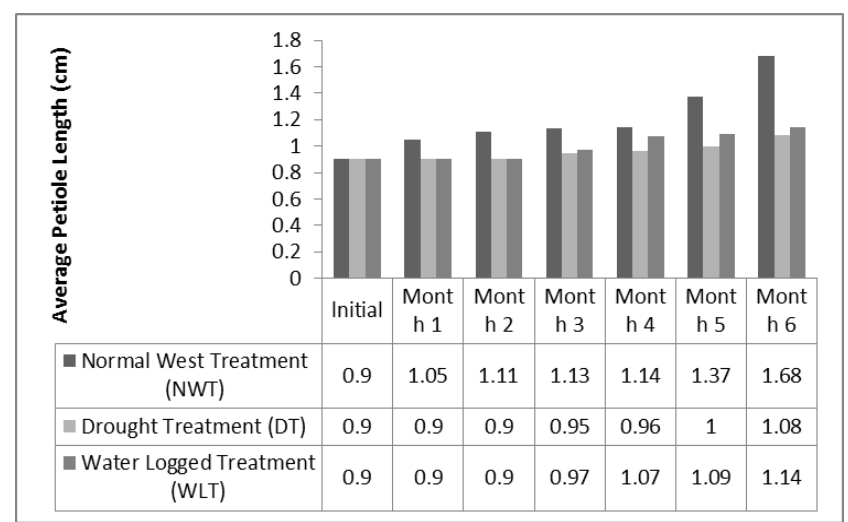

Fig. 7: Effect of Water Regime on the Growth of the Petiole Length of Vernonia amygdalina.



Fig. 8: Effect of Water Regime on the Growth of the Root Length of Vernonia amygdalina. 
International Journal of Engineering Applied Sciences and Technology, 2019

Vol. 4, Issue 7, ISSN No. 2455-2143, Pages 222-228

Published Online November 2019 in IJEAST (http://www.ijeast.com

Table 1: Average (mean) values of all the morphological growth characters at the Initial and next six months after the application of treatment.

\begin{tabular}{|c|c|c|c|c|c|c|c|c|c|c|c|c|c|c|c|c|c|c|c|c|c|}
\hline & \multicolumn{3}{|c|}{$\begin{array}{l}0 \text { initial month } \\
\text { (May) }\end{array}$} & \multicolumn{3}{|c|}{$1^{\text {st }}$ month (June) } & \multicolumn{3}{|c|}{$2^{\text {nd }}$ month (July) } & \multicolumn{3}{|c|}{$\begin{array}{l}3^{\text {rd }} \text { month } \\
\text { (August) }\end{array}$} & \multicolumn{3}{|c|}{$\begin{array}{l}4^{\text {th }} \text { month } \\
\text { (September) }\end{array}$} & \multicolumn{3}{|c|}{$5^{\text {th }}$ month (October) } & \multicolumn{3}{|c|}{$\begin{array}{c}6^{\text {th }} \text { month } \\
\text { (November) }\end{array}$} \\
\hline & $\begin{array}{c}\mathrm{NW} \\
\mathrm{T}\end{array}$ & DT & WLT & $\begin{array}{c}\text { NW } \\
\text { T }\end{array}$ & DT & $\begin{array}{c}\mathrm{WL} \\
\mathrm{T}\end{array}$ & $\begin{array}{c}\text { NW } \\
\text { T }\end{array}$ & DT & $\begin{array}{c}\text { WL } \\
\mathrm{T}\end{array}$ & $\begin{array}{c}\text { NW } \\
\text { T }\end{array}$ & DT & $\begin{array}{c}\mathrm{WL} \\
\mathrm{T}\end{array}$ & NWT & $\begin{array}{l}\mathrm{D} \\
\mathrm{T}\end{array}$ & $\begin{array}{c}\mathrm{WL} \\
\mathrm{T}\end{array}$ & NWT & DT & $\begin{array}{c}\mathrm{WL} \\
\mathrm{T}\end{array}$ & NWT & DT & $\begin{array}{c}\mathrm{WL} \\
\mathrm{T}\end{array}$ \\
\hline $\begin{array}{c}\mathrm{SH} \\
(\mathrm{cm})\end{array}$ & 6.50 & 6.50 & 6.50 & 7.00 & 6.50 & 6.50 & 7.43 & 6.50 & 6.58 & 7.93 & 6.75 & 6.90 & 10.53 & $\begin{array}{c}6 . \\
90\end{array}$ & 7.18 & 13.53 & 7.28 & 7.55 & 13.56 & 7.53 & 9.50 \\
\hline $\begin{array}{l}\mathrm{LL} \\
(\mathrm{cm})\end{array}$ & 3.20 & 3.20 & 3.20 & 3.23 & 3.20 & 3.20 & 3.48 & 3.20 & 3.20 & 3.55 & 3.22 & 3.29 & 3.84 & $\begin{array}{l}3 . \\
23\end{array}$ & 3.36 & 3.88 & 3.25 & 3.58 & 4.38 & 3.34 & 3.80 \\
\hline $\begin{array}{l}\mathrm{LB} \\
(\mathrm{cm})\end{array}$ & 1.90 & 1.90 & 1.90 & 2.30 & 1.90 & 1.90 & 2.35 & 1.90 & 1.90 & 2.40 & 2.14 & 2.21 & 2.53 & $\begin{array}{l}2 . \\
20\end{array}$ & 2.27 & 2.75 & 2.31 & 2.55 & 3.03 & 2.50 & 2.70 \\
\hline $\begin{array}{l}\mathrm{PG} \\
(\mathrm{cm})\end{array}$ & 1.30 & 1.30 & 1.30 & 1.68 & 1.30 & 1.30 & 1.80 & 1.30 & 1.30 & 2.00 & 1.49 & 1.57 & 2.10 & $\begin{array}{l}1 . \\
63\end{array}$ & 1.70 & 2.27 & 1.83 & 2.00 & 2.41 & 1.91 & 2.27 \\
\hline $\begin{array}{l}\mathrm{PL} \\
(\mathrm{cm})\end{array}$ & 0.90 & 0.90 & 0.90 & 1.05 & 0.90 & 0.90 & 1.11 & 0.90 & 0.90 & 1.13 & 0.95 & 0.97 & 1.14 & $\begin{array}{l}0 . \\
96\end{array}$ & 1.07 & 1.37 & 1.00 & 1.09 & 1.68 & 1.08 & 1.14 \\
\hline $\begin{array}{l}\mathrm{LR} \\
(\mathrm{cm})\end{array}$ & 0.50 & 0.50 & 0.50 & 0.68 & 0.50 & 0.50 & 0.93 & 0.50 & 0.58 & 1.05 & 0.78 & 0.82 & 1.27 & $\begin{array}{l}0 . \\
86\end{array}$ & 1.01 & 1.43 & 0.94 & 1.13 & 1.70 & 0.98 & 1.36 \\
\hline $\begin{array}{c}\text { FWR } \\
(\mathrm{g})\end{array}$ & 0.50 & 0.50 & 0.50 & 0.58 & 0.50 & 0.50 & 0.72 & 0.50 & 0.52 & 0.81 & 0.57 & 0.59 & 0.90 & $\begin{array}{l}0 . \\
62\end{array}$ & 0.64 & 0.96 & 0.65 & 0.66 & 1.12 & 0.82 & 0.93 \\
\hline $\begin{array}{c}\text { FWL } \\
(\mathrm{g})\end{array}$ & 2.20 & 2.20 & 2.20 & 2.28 & 2.20 & 2.20 & 2.30 & 2.20 & 2.22 & 2.41 & 2.25 & 2.40 & 2.45 & $\begin{array}{l}2 . \\
31\end{array}$ & 2.43 & 2.53 & 2.37 & 2.46 & 2.58 & 2.39 & 2.53 \\
\hline
\end{tabular}

Stem Height (SH), Leaf Length (LL), Leaf Breadth (LB), Plant Girth (PG), Petiole Length (PL), Length of Root (LR), Fresh Weight of Root (FWR) and Fresh Weight of Leaf (FWL). 


\section{International Journal of Engineering Applied Sciences and Technology, 2019 \\ Vol. 4, Issue 7, ISSN No. 2455-2143, Pages 222-228 \\ Published Online November 2019 in IJEAST (http://www.ijeast.com)}

\section{CONCLUSION AND RECOMMENDATION}

\section{A. Conclusion}

Although $V$. amygdalina can be planted using all types of water treatment as observed in this experiment, the result of the three watering regime shows that the best and favourable growth environment for this plant is normal wet treatment water regime (wetting everyday) followed by water logged treatment water regime (excess water) and the least favourable growth environment which can be manageable in absence of the two first mentioned water treatment is the drought treatment (wetting once a week). The amount of water available to plant will affect the rate of photosynthesis. If the plant does not have enough water, the plant's stomata will shut and the plant will be deprived of carbon dioxide and if there is excess of water, the photosynthetic activities is also affected.

\section{B. Recommendation}

In case of water logged or riverside cultivation, it is advisable that farmers prepare a nursery growth for the plant to establish before transplanting into the water logged soil and the plant should be carefully monitored as it will not show any meaningful differences at the first month. The plant will try to adapt to the new environment. Since the plant already have established roots, it is easier to germinate than introducing directly into the water logged area without any nursery establishment, this will lead to the death of the plant since it has no root that will help to adapt to the new environment.

\section{REFERENCES}

1. Farooq. M., Wahid A., Kobayashi N., Fujita D., Basra S.M.A. (2009). Plant drought stress: effects, mechanisms and management. Agronomy for Sustainable Development, 29: (pp. 185-212). https://doi.org/10.1051/agro:2008021.

2. Riccardi, M., Pulvento, C., Patanè, C, Albrizio, R, Barbieri, G. (2016). Drought stress response in long storage tomatoes: Physiological and biochemical traits. Scientia Horticulturae, 200: (pp. 25-35). doi: https://doi.org/10.1016/j.scienta.2015.12.049.

3. Rea, N., Ganf, G.G. (1994). How emergent plants experience water regime in a mediterranean-type wetland. Aquatic Botany, 49: (pp. 117-136). doi:10.1016/0304-3770(94)90033-7.

4. Hutchinson, J., and Dalziel, J.M. (1963). Flora of West Tropical Africa. Crown Agents; London, (pp. 452).

5. Bonsi, M.L.K., Osuji, P.O Tuah, A.K., and Umunna, N.N. (1995a). Vernonia amygdalina as a supplement to teff straw (Eragrostis tef.) fed to Ethiopian Menz sheep. Agroforestry Systems 31(3): (pp. 229-241).

6. Buttler, G.W. and Bailey, R.W. (1973). Chemistry and Biochemistry of Herbage. Vol. 1 Academic Press, London and New York. (pp. 700).

7. Ologunde, M.O., Ayorinde, F.O., Shepard, R.K., Afolabi, O.A and Oke, O.L. (1992). Sterols of Seeds oils of Vernonia galanesis, Amaranthus cruentus, Amaranthus caudatus, Amarathus hybrids and Amaranthus hypochondriacus growth in the humid tropics. J. of Food Agric. 58: (pp. 221-225).

8. Bonsi, M.L.K., Osuji, P.O., and Tuah, A.K. (1995b). Effect of supplementing teff straw with different levels of leucaena or sesbania leaves on then degradability of teff straw, sesbania, leucaena, tagasaste and vernonia and on certain rumen and blood metabolites in Ethiopia Menz sheep, Animal Feed Science and Technology, 52: 101-129.

9. Leung, W.T.W., Busson, F., and Jardin, C. (1968). Food composition table for Africa. FAO press, Rome, Italy. (pp. 306).

10. Boyer, J.S. and Westgate, M.E. (2004). Grain yields with limited water. Journal of Experimental Botany. 55(407): (pp.2385-2394).

11. Steven, C., Huber,H.,Hugo, H., Rogers, V., and Fred, L.M. (1984). Effects of Water Stress on Photosynthesis and Carbon Partitioning in Soybean (Glycine max IL.IMerr.) Plants Grown in the Field at Different CO2 Levels. Plant Physiol. 76: (pp. 244249).

12. Hardwick, R.C. (1984). Some recent developments in Growth Analysis- A review. Annual Botany. 54. (pp. 807-812).

13. Jackson, M.B. (1985). Ethylene and the responses of plants to soil Waterlogging and submergence. Annu. Rev. Plant Physiology. 36: (pp. 145-174).

14. Justin, S.H.R.W. and Armstrong, W. (1987). The anatomical characteristics of roots and plants response to soil flooding. New Phytologist. 105: (pp. 465-495).

15. Jackson, M.B. (1990). Communication between the roots and shoots of flooded plants In: Importance of root to shoot communication in the responses to environmental stress. Davies, W.S and Jeffcoat, B. (eds). British Society for Plant Growth Regulation, Bristol, U.K., (pp. 115-1133).

16. Rahman, M.U., Gul, S., and Ahmad, I. (2004). Effects of water stress on growth and photosynthetic pigments of corn (Zea mays) cultivars. International Journal of Agric. Biology, 4: (pp. 652-655).

17. Johnston, C. B. (2005). Physiological processes limiting plant productivity. London, Butterworths, (pp 331-344). 


\section{International Journal of Engineering Applied Sciences and Technology, 2019 \\ Vol. 4, Issue 7, ISSN No. 2455-2143, Pages 222-228 \\ Published Online November 2019 in IJEAST (http://www.ijeast.com)}

18. Rashidi, M., and Seyfi, K. (2006). Effect of Water Stress on Crop Yield and Yield Components of Cantaloupe. International Journal of Agriculture \& Biology, 9(2): (pp. 271-273).

19. Sena, G.A.R. and Kozlowski, T.T. (1980). Growth responses and adaptations of Fraxinus pennsylvanica seedlings to flooding. Plant physiology, 66: (pp. 267271).

20. Jockson, M.B. and Drew, M.C. (1984). Effects of flooding on growth and metabolism of herbaceous plants In: Flooding and Plant Growth. Kozlowski, T. (ed). Academic Press, Newyork, NY, USA. (pp. 47128).

21. Causton, D. R., and Venus, J.C. (1981). The Biometry of Plant Growth. Edward Arnord Press, London. (pp. 307).

22. Paul, J.K. (1963). Water Stress and Plant Growth. Agronomy Journal. 55: (pp. 31-35).

23. Westoby, M. (1982). Frequency distributions of plant size during competitive growth of stands: The operations of distribution-modifying functions. Ann. Botany, 50: (733-735).

24. Ohigashi, H., Jisaka, M., Takagaki, T., Nozaki, H., Tada, T., Huffman, M.A., Nishida, T., Kaji, M., and Koshimizu, M. (1991). Bitter principle and a related steroid glucoside of Vernonia amygadalina, a possible medicinal plant for wild chimpanzees. Agricultual and Biological Chemistry. 55(4): (pp. 1201-1203).

25. Ackerson, R. C., Krieg, D.R., Haring, C.L., and Chang, N. (1977). Effects of plant water status on stomatal activity, photosynthesis, and nitrate reductase activity of field grown cotton. Crop Science, 17: (pp. 81-84).

26. Balch, M.P., Eugenio, G., Manuel, S.N., and Magdalena, H.E. (1996). Effects of water stress on plant growth and root proteins in three cultivars of rice (Oryza sativa) with different levels of drought tolerance. Blackwell Publishing. (pp. 284-290).

27. Saba J., Moghaddam M., Ghassemi K., Nishabouri M. R. (2001). Genetic properties of drought resistance indices. Journal of Agricultural Science and Technology, 3: (pp. 43-49).

28. Villalobos M. A., Bartels D., Iturringa G. (2004). Stress tolerance and glucose insensitive phenotypes in Arabidopsis overexpressing the CpMYB10 transcription factor gene. Plant Physiology, 135(1): (pp. 309-324). https://doi.org/10.1104/pp.103.034199
29. Eriș, A., Sivritepe, N. and Sivritepe, H.Ö. (1998). Some physiological and morphological responses of grapevines to water stress. Bağcılık Sempozyumu. Yalova, (pp. 64-69).

30. Bertamini, M., Zulini, L., Muthuchelian, K. and Nedunchezhian, N. (2006) Effect of water deficit on photosynthetic and other physiological responses in grapevine (Vitis vinifera L. cv. Riesling) plants. Photosynthetica, 44(1): (pp. 151-154).

31. Cramer, G.R. (2010) Abiotic stress and plant responses from the whole vine to the genes. Aust. J. Grape Wine R. 16: (pp. 86-93).

32. Bauerle, T.L., Richards, J.H., Smart, D.R. and Eissenstat, D.M. (2008) Importance of internal hydraulic redistribution for prolonging the lifespan of roots in dry soil. Plant Cell Environ. 31(2): (pp. 177186).

33. Satisha, J., Prakash, G.S. and Venugopalan, R. (2006). Statistical modeling of the effect of physiobiochemical parameters on water use efficiency of grapevarieties, rootstocks and their stionic combinations under moisture stres conditions. Turk $J$. Agric. For. 30: (pp. 261-271).

34. Lovisolo, C., Perrone, I., Carra, A., Ferrandino, A., Flexas, J., Medrano, H. and Schubert, A. (2010). Drought-induced changes in development and function of grapevine (Vitis spp.) organs and in their hydraulic and non-hydraulic interactions at the whole plant level: a physiological and molecular update. Funct Plant Biol. 37(2): (pp. 98-116).

35. Kliewer, W.M., Freeman, B.M. and Hossom, C. (1983). Effect of irrigation, crop level and potassium fertilization on Carignane vines I. Degree of water stres and effect on growth and yield. Am.J.Enol.Vitic. 34(3): (pp. 186-196).

36. Poni, S., Lakso, A.N., Turner, J.R. and Melious, R.E. (1993). The effects of pre- and post veraison water stress on growth and physiology of potted Pinot Noir grapevines at varying crop levels. Vitis, 32: (pp. 207214).

37. Winkel, T. and Rambal, S. (1993). Influence of water stress on grapevines growing in the field; from leaf to whole-plant response. Aust. J. Plant Physiol. 20 (2): (pp. 143-157).

38. Paranychianakis, N.V., Aggelides, S. and Angelakis, A.N. (2004). Influence of rootstock, irrigation level and recycled water on growth and yield of Soultanina grapevines. Agr. Water Manage, 69: (pp. 13-27).

39. Dry, P.R., Loveys, B.R. and During, H. (2000). Partial drying of the root zone of grape. II. Changes in the pattern of root development. Vitis, 39: (pp. 912). 